\title{
First autochthonous human West Nile virus infections in the Netherlands, July to August 2020
}

Danique RM Vlaskamp ${ }^{1,2}$, Steven FT Thijsen 2,3 , Johan Reimerink ${ }^{2,4}$, Pieter Hilkens ${ }^{1}$, Willem H Bouvy ${ }^{5}$, Sabine E Bantjes ${ }^{4}$, Bart JM Vlaminckx ${ }^{6}$, Hans Zaaijer ${ }^{7}$, Hans HTC van den Kerkhof ${ }^{4}$, Stijn FH Raven ${ }^{2,4,8}$, Chantal BEM Reusken ${ }^{2,4}$

1. Department of Neurology, St. Antonius hospital, Nieuwegein, the Netherlands

2. These authors contributed equally

3. Department of Medical Microbiology and Immunology, Diakonessenhuis Hospital, Utrecht, the Netherlands

4. Centre for Infectious Disease Control, National Institute for Public Health and the Environment, Bilthoven, the Netherlands

5. Department of Neurology, Diakonessenhuis Hospital, Utrecht, the Netherlands

6. Department of Medical Microbiology and Immunology, St. Antonius Hospital, Nieuwegein, the Netherlands

7. Sanquin Blood Supply Foundation and Amsterdam University Medical Centre, Amsterdam, the Netherlands

8. Department of Infectious Diseases, Public Health Service region Utrecht, Utrecht, the Netherlands

Correspondence: Chantal Reusken (chantal.reusken@rivm.nl)

Citation style for this article:

Vlaskamp Danique RM, Thijsen Steven FT, Reimerink Johan, Hilkens Pieter, Bouvy Willem H, Bantjes Sabine E, Vlaminckx Bart JM, Zaaijer Hans, van den Kerkhof Hans HTC, Raven Stijn FH, Reusken Chantal BEM. First autochthonous human West Nile virus infections in the Netherlands, July to August 2020. Euro Surveill. 2020;25(46): pii=2001904. https://doi.org/10.2807/1560-7917.ES.2020.25.46.2001904

In October 2020, the first case of autochthonous West Nile virus neuroinvasive disease was diagnosed in the Netherlands with a presumed infection in the last week of August. Investigations revealed five more cases of local West Nile virus (WNV) infection. The cases resided in a region where WNV was detected in a bird and mosquitoes in August 2020. Molecular analysis was successful for two cases and identified the presence of WNV lineage 2 .

In October 2020, a case of autochthonous West Nile virus neuroinvasive disease (WNND) was diagnosed in the Netherlands with a presumed date of infection in the last week of August. Additional epidemiological investigations and retrospective serological analyses of cerebrospinal fluid (CSF) from patients with neurological disease of unknown but suspected viral aetiology sampled between August and September 2020, revealed five more cases of West Nile virus (WNV) infection. Three of them had WNND and two had West Nile fever (WNF) [1,2]. The cases were infected between July and August 2020, and all of them resided in a region where WNV lineage 2 was detected in a bird and mosquitoes in August 2020 [3]. Molecular analysis was successful for two cases showing the presence of WNV lineage 2.

\section{Cases 1 and 2}

At the end of August 2020, a person in their mid-70s (Case 1) developed a generalised rash, as did their spouse (Case 2, also in their mid-70s) one day later. Both cases' rashes disappeared after a few days, but Case 1 developed a high fever with severe malaise on day 5 after symptom onset. Case 1 was weak, unable to walk and barely able to speak. From day 6 onwards,
Case 1 further deteriorated, with a headache, vomiting, urinary incontinence, confusion and slowness of thought and movements, and was admitted to Hospital A (day 8). At admission, Case 1 was disoriented in time and place and had cognitive impairment and walking apraxia. Neurological examination revealed no focal neurological deficits. Clinically, Case 1 was diagnosed with an encephalitis.

Laboratory results, chest X-ray and urine investigation showed no signs of active infection (Supplementary Table). CSF investigation revealed mild pleocytosis with mononuclear cells and a slightly elevated protein level. Serological and CSF investigations excluded a range of infectious diseases, including infection with tick-borne encephalitis virus (TBEV). Magnetic resonance imaging revealed no abnormalities. Clinically, Case 1's cognition slowly improved, but at discharge (day 40 post symptom onset) the patient was still unable to walk and was referred to a rehabilitation centre.

In early October, continued laboratory investigations at the National Institute for Public Health and the Environment (RIVM) confirmed WNV infection as the causative agent for WNND (Table; [1]). Three consecutive serum samples were positive for WNV IgM and IgG in an ELISA (Euroimmun, Lübeck, Germany); they were also positive for WNV IgG, but not Usutu virus (USUV) or TBEV IgG, in a multiplex flavivirus protein-array [4]. Comparative plaque reduction neutralisation test (PRNT) ${ }_{50}$ for WNV and USUV [5] confirmed the presence of WNV neutralising capacity, but not USUV. Reversetranscription (RT)-PCR on the cell-pellet of whole blood taken on day 42 was positive (cycle threshold (Ct) value: 33 ) for WNV lineage 2 but not WNV lineage 1 (in 
Sampling schedule and flavivirus diagnostic results, autochthonous human cases of West Nile virus infection, the Netherlands, August-October $2020(\mathrm{n}=6)$

\begin{tabular}{|c|c|c|c|c|c|c|c|c|c|c|c|}
\hline \multirow[b]{2}{*}{ Sample type } & \multicolumn{3}{|c|}{ Case 1} & \multirow{2}{*}{$\begin{array}{l}\text { Case } 2 \\
\text { Serum/ } \\
\text { whole } \\
\text { blood }\end{array}$} & \multicolumn{2}{|c|}{ Case 3} & \multirow{2}{*}{$\begin{array}{c}\text { Case } 4 \\
\text { Serum/ } \\
\text { whole } \\
\text { blood }\end{array}$} & \multicolumn{2}{|c|}{ Case 5} & \multicolumn{2}{|c|}{ Case 6} \\
\hline & Serum & Serum & $\begin{array}{l}\text { Serum/ } \\
\text { whole } \\
\text { blood }\end{array}$ & & CSF & $\begin{array}{c}\text { Serum/ } \\
\text { whole blood }\end{array}$ & & CSF & $\begin{array}{c}\text { Serum/ } \\
\text { whole blood }\end{array}$ & CSF & $\begin{array}{l}\text { Serum/ } \\
\text { whole } \\
\text { blood }\end{array}$ \\
\hline $\begin{array}{l}\text { Sampling } \\
\text { month and } \\
\text { days post } \\
\text { symptom } \\
\text { onset }\end{array}$ & $\begin{array}{c}\text { Sep } \\
19 \mathrm{dpo}\end{array}$ & $\begin{array}{c}\text { Sep } \\
29 \mathrm{dpo}\end{array}$ & $\begin{array}{l}\text { Oct } \\
43 \mathrm{dpo}\end{array}$ & $\begin{array}{c}\text { Oct } \\
46 \mathrm{dpo}\end{array}$ & $\begin{array}{c}\text { Aug } \\
16 \mathrm{dpo}\end{array}$ & $\begin{array}{c}\text { Oct } \\
68 \mathrm{dpo}\end{array}$ & $\begin{array}{l}\text { Oct } \\
68 \mathrm{dpo}\end{array}$ & $\begin{array}{l}\text { Sep } \\
7 \text { dpo }\end{array}$ & $\begin{array}{l}\text { Oct } \\
65 \mathrm{dpo}\end{array}$ & $\begin{array}{c}\text { Aug } \\
25 \text { dpo }\end{array}$ & $\begin{array}{c}\text { Oct } \\
98 \mathrm{dpo}\end{array}$ \\
\hline $\begin{array}{l}\text { WNV ELISA } \\
\operatorname{lgM} / \operatorname{lgg}^{a}\end{array}$ & $2.47 / 1.71$ & $2.72 / 1.91$ & $2.50 / 3.08$ & $4.03 / 5.47$ & $\begin{array}{c}6.83 / \\
\text { Neg }\end{array}$ & $\mathrm{Neg} / 4.83$ & $2.72 / 4.43$ & $1.89 / 5.21$ & $\mathrm{Neg} / 5.02$ & $\begin{array}{c}3.83 / \\
\mathrm{Neg}\end{array}$ & $\begin{array}{l}\mathrm{Neg} / \\
\mathrm{Neg}\end{array}$ \\
\hline $\begin{array}{l}\text { WNV RT-PCR } \\
\text { Ln } 2 / \operatorname{Ln} 1\end{array}$ & NT & NT & Pos Ct 33 & Pos Ct 34 & NT & Neg & Neg & NT & Neg & NT & Neg \\
\hline $\begin{array}{l}\text { WNV } \\
\text { PRNT50 / } \\
\text { Usutu } \\
\text { PRNT50 } \\
\end{array}$ & $1,024 / \mathrm{NT}$ & $1,024 / \mathrm{NT}$ & $512 / \mathrm{Neg}$ & $1024 / \mathrm{Neg}$ & NT & $512 / \mathrm{NT}$ & $256 / N T$ & NT & $256 / N T$ & NT & NT \\
\hline $\begin{array}{l}\text { Multiplex } \\
\text { flavivirus } \\
\text { NS1 micro- } \\
\text { array: WNV } \\
\text { Ln 2/Ln 1c } \\
\end{array}$ & $108 /$ Neg & $121 / 63$ & $258 / 86$ & $774 / 307$ & NT & $>1,280 / 927$ & $402 / 270$ & NT & $>1,280 />1,280$ & NT & $63 / 27$ \\
\hline USUV & Neg & $\mathrm{Neg}$ & Neg & 84 & NT & 262 & 79 & NT & 331 & NT & NT \\
\hline TBEV & $\mathrm{Neg}$ & $\mathrm{Neg}$ & Neg & $\mathrm{Neg}$ & NT & 53 & $\mathrm{Neg}$ & NT & 72 & NT & NT \\
\hline
\end{tabular}

Ct: PCR cycle threshold; CSF: cerebrospinal fluid; dpo: days post onset of symptoms; ELISA: enzyme-linked immunosorbent assay; Ln 1: lineage 1; Ln 2: lineage 2; Neg: negative; NS1: flavivirus non-structural protein 1; NT: not tested; Pos: positive; PRNT: plaque reduction neutralisation assay; TBEV: tick-borne encephalitis virus; USUV: Usutu virus; WNV: West Nile virus.

a Optical density ratios.

b Neutralising antibody titres.

c IgG titres (cut-off titre is 10).

Reactivity with WNV Ln 1, USUV and/or TBEV NS1 is cross-reactivity of WNV Ln 2 NS1 directed IgG [4].

house [6-8]). Amplicon-based whole genome sequencing identified two WNV lineage 2 genome fragments (417 and 415 bp) identical to a WNV sequence found in a Dutch mosquito pool (GenBank MW228499 and MW228500; GenBank MWo36633 [3]).

Following Case 1's diagnosis, whole blood was collected from Case 2 on day 45 post rash onset. ELISA, protein micro-array, PRNT $_{50}$ and RT-PCR confirmed WNF caused by a WNV lineage 2 strain [1].

Both cases had no relevant travel history and had no recollection of mosquito bites in the weeks before onset of symptoms; however, they lived in the region where WNV was found in a bird and mosquitoes [3].

\section{Active case finding}

To rapidly investigate the extent of WNV circulation and human infection in the affected region, two regional hospitals were asked to submit CSF of patients who were hospitalised in August and September 2020 with unexplained neurological disease of suspected viral origin to RIVM to analyse for the presence of WNV IgM and IgG (ELISA).
Analysis of CSF from 64 patients of Hospital B for the presence of WNV IgM and IgG identified a second patient with WNND (Case 3). Further, analyses of CSF of 37 patients with neurological disease in Hospital A confirmed two additional WNND patients (Cases 5 and 6). For all cases, laboratory investigations corroborated the diagnoses (Table; Supplementary Table).

\section{Cases 3 to 6}

Case 3, an otherwise healthy person in their mid-30s, visited their general physician in mid-August for severe headache that had started 8 days earlier, as well as muscle ache and skin rash that had started 1 day prior. Doxycycline was prescribed for presumed leptospirosis. The case was referred to the emergency ward 2 days later with worsening symptoms (fever of $39.5^{\circ} \mathrm{C}$, vertigo, neck pain, nausea and vomiting). Neurological examination was normal (no neck stiffness) except for a first-degree horizontal nystagmus. Laboratory results showed normal infection parameters (Supplementary Table). A lumbar puncture showed mild pleocytosis of mostly mononuclear cells (93\%) and a mildly elevated protein. The case was treated with acyclovir, ceftriaxone and trimethoprim/sulfamethoxazole. Therapy was stalled when test results for Leptospira spp., herpes simplex virus, varicella zoster virus, severe acute 
respiratory syndrome coronavirus 2 and Borrelia spp. were negative. Symptoms improved rapidly and the case was discharged on day 15 after the first symptom onset. Case 3's outpatient visit 2 months later revealed mild persisting fatigue and irritability.

Epidemiological investigation for Case 3 revealed that their partner (Case 4), in their early 305, had experienced a rash, retro-orbital pain and malaise in the same period, but without progression to neurological disease. Laboratory investigation confirmed that Case 4 had a recent WNV infection (Table).

Cases 3 and 4 had not travelled outside the Netherlands in the 2 weeks before the onset of symptoms. Both lived in the region where the WNV-infected bird and mosquitoes were found [3] and experienced mosquito bites in the week before onset of symptoms.

Case 5 was in their late 60 s and resided in the same municipality as Cases 1 and 2. Case 5 experienced illness at the end of August. Case 6 was an unrelated case in their mid-40s that lived ca $20 \mathrm{~km}$ from the location where the WNV-positive bird and mosquitoes were found. Case 6's first day of illness was at the end of July 2020. They received immunosuppressive therapy since early October 2020, which might explain the absence of ELISA-detectable WNV IgG and IgM in serum collected on day 98 after symptom onset. Both cases had not travelled outside the Netherlands and had no recollection of mosquito bites in the weeks before disease onset.

\section{Ethical statement}

The diagnostics performed herein were either part of routine clinical microbiology practice to establish the cause of illness of unexplained cases in medical care or part of public health usual practice.

\section{Discussion}

The identification of the first six clinical cases of autochthonous human WNV infection in the Netherlands confirms this mosquito-borne virus' potential to expand its geographical distribution northward. Since 2018, WNV has established a presence in Europe as far north as Germany [9], though areas in south-eastern Europe still report the highest number of human cases. As at 12 November 2020, 315 WNV cases from eight countries have been notified to the European Centre for Disease Prevention and Control, with the majority of cases from Greece $(n=143)$, Italy $(n=66)$ and Spain $(n=77)[10]$.

Between August and September 2020, local presence of WNV in the Netherlands was observed for the first time with the detection of WNV RNA in a common whitethroat and in two Culex spp. mosquito pools in the municipality of Utrecht [3]. RIVM announced this first observation to the public on 16 September 2020 [11] and details were shared with infectious disease professionals on 17 September 2020 using a weekly national alerting system [12]. The first identification of autochthonous cases of WNND in the Netherlands underlines the importance of a One Health approach to surveillance for arboviruses and rapid risk communication to clinical professionals and the general public.

The clinical and epidemiological investigations described herein focused on a specific region and were triggered by the possible enzootic presence of WNV. Following the diagnosis of the first WNND case, local syndrome-based investigations identified three more cases of WNND (Cases 3,5 and 6) and two cases of WNF (Cases 2 and 4). Research has shown that for each case of WNND detected, on average 250 other mild or asymptomatic infections occur $[13,14]$; based on the four known WNND cases in the region described here, it can be expected that hundreds of people were infected in this area during the summer months. The extent of WNV presence in Utrecht and adjacent regions will be investigated through (i) retrospective screening of CSF of unexplained neurological patients and (ii) regional seroprevalence studies in humans, as well as (iii) entomological and (iv) veterinary research.

As WNV can be transmitted through blood transfusion, it is important to determine the geographical extent of circulation. In line with European Union directives, safety measures were applied to blood donations from donors residing or donating in the affected areas [15]. In October 2020, a seventh case became infected in another region in the Netherlands (Arnhem) and blood safety measures were expanded accordingly [16].

Although it remains to be seen whether WNV will overwinter and maintain an enzootic presence in the Netherlands, as can be expected based on spatial risk analysis and in analogy with the situation in Germany $[9,17]$, further multidisciplinary surveillance and communication strategies will be developed in the coming months to monitor the extent of spread and increase awareness of the disease among clinicians and the general public.

\section{Acknowledgements}

We thank Prof. D. van de Beek (Amsterdam UMC) for his clinical input regarding Cases 1 and 2. We thank Fion Brouwer, Marieke Hoogerwerf, Ramona Mögling, Bas van der Veer, Jeroen Cremer, Sophie van Tol, Gert-Jan Godeke, Florian Zwagemaker, Dirk Eggink and Matthijs Welkers (RIVM) for the excellent laboratory support. We thank Karlijn Schaffer, Anniek Reinhold and Nadieh Taks from the public health service region Utrecht for their assistance in the source investigation and providing the additional blood samples.

\section{Conflict of interest}

None declared.

Authors' contributions

DV, ST, PH, WH, BV: treating physicians, co-wrote manuscript 
JR, CR: West Nile virus preparedness, reference laboratory work, co-wrote manuscript

ST: epidemiological investigations, co-wrote manuscript

SB, HZ, HK: West Nile virus preparedness, public health response, co-wrote manuscript

\section{References}

1. European Commission. Decisions COMMISSION IMPLEMENTING DECISION (EU) $2018 / 945$ of 22 June 2018 on the communicable diseases and related special health issues to be covered by epidemiological surveillance as well as relevant case definitions. Official Journal of the European Union. Luxembourg: Publications Office of the European Union. 6.7.2018: L 170/5.Available from: https://eur-lex.europa.eu/ legal-content/EN/TXT/PDF/?uri=CELEX:32018D0945\&from=EN \#page $=5$

2. Silk BJ, Astles JR, Hidalgo J, Humes R, Waller LA, Buehler JW, et al. Differential West Nile fever ascertainment in the United States: a multilevel analysis. Am J Trop Med Hyg. 2010;83(4):795-802. https://doi.org/10.4269/ ajtmh.2010.10-0161 PMID: 20889867

3. Sikkema RS, Schrama M, van den Berg T, Morren J, Munger $\mathrm{E}$, Krol L, et al. Detection of West Nile virus in a common whitethroat (Curruca communis) and Culex mosquitoes in the Netherlands, 2020. Euro Surveill. 2020;25(40). https:// doi.org/10.2807/1560-7917.ES.2020.25.40.2001704 PMID: 33034280

4. Cleton NB, Godeke GJ, Reimerink J, Beersma MF, Doorn HR, Franco L, et al. Spot the difference-development of a syndrome based protein microarray for specific serological detection of multiple flavivirus infections in travelers. PLoS Negl Trop Dis. 2015;9(3):e0003580. https://doi.org/10.1371/journal. pntd.0003580 PMID: 25767876

5. Faggioni G, De Santis R, Pomponi A, Grottola A, Serpini GF, Meacci $M$, et al. Prevalence of Usutu and West Nile virus antibodies in human sera, Modena, Italy, 2012. J Med Virol. 2018;90(10):1666-8. https://doi.org/10.1002/jmv.25230 PMID: 29797606

6. Lanciotti RS, Kerst AJ, Nasci RS, Godsey MS, Mitchell CJ, Savage HM, et al. Rapid detection of west nile virus from human clinical specimens, field-collected mosquitoes, and avian samples by a TaqMan reverse transcriptase-PCR assay. Clin Microbiol. 2000;38(11):4066-71. https://doi.org/10.1128/ JCM.38.11.4066-4071.2000 PMID: 11060069

7. Lustig Y, Mannasse B, Koren R, Katz-Likvornik S, Hindiyeh $M$, Mandelboim M, et al. Superiority of West Nile Virus RNA Detection in Whole Blood for Diagnosis of Acute Infection. Clin Microbiol. 2016;54(9):2294-7. https://doi.org/10.1128/ JCM.01283-16 PMID: 27335150

8. Rios M, Daniel S, Chancey C, Hewlett IK, Stramer SL. West Nile virus adheres to human red blood cells in whole blood. Clin Infect Dis. 2007;45(2):181-6. https://doi.org/10.1086/518850 PMID: 17578776

9. Ziegler U, Santos PD, Groschup MH, Hattendorf C, Eiden M, Höper D, et al. West Nile Virus Epidemic in Germany Triggered by Epizootic Emergence, 2019. Viruses. 2020;12(4):E448. https://doi.org/10.3390/v12040448 PMID: 32326472

10. European Centre for Disease Prevention and Control (ECDC). Communicable Disease Threats Report week 46, 8-14 November 2020. Stockholm: ECDC; 2020. Available from: https://www.ecdc.europa.eu/sites/default/files/documents/ communicable-disease-threats-report-14-nov-2020-public_o. pdf

11. National Institute for Public Health and the Environment (RIVM). Vogel besmet met westnijlvirus. [Bird with west Nile virus infection]. Bilthoven: RIVM; 2020. Dutch. Available from: https://www.rivm.nl/nieuws/vogel-besmet-met-westnijlvirus

12. Rahamat-Langendoen JC, van Vliet JA, Suijkerbuijk AW. Recognition of threats caused by infectious diseases in the Netherlands: the early warning committee. Euro Surveill. 2006;11(12):242-5. https://doi.org/10.2807/esm.11.12.00672en PMID: 17370963

13. Busch MP, Wright DJ, Custer B, Tobler LH, Stramer SL, Kleinman $\mathrm{SH}$, et al. West Nile virus infections projected from blood donor screening data, United States, 2003. Emerg Infect Dis. 2006;12(3):395-402. https://doi.org/10.3201/eid1205.051287 PMID: 16704775

14. Carson PJ, Borchardt SM, Custer B, Prince HE, Dunn-Williams J, Winkelman V, et al. Neuroinvasive disease and West Nile virus infection, North Dakota, USA, 1999-2008. Emerg Infect
Dis. 2012;18(4):684-6. https://doi.org/10.3201/eid1804.111313 PMID: 22469465

15. European Commission. COMMISSION DIRECTIVE 2014/110/ EU of 17 December 2014 amending Directive 2004/33/EC as regards temporary deferral criteria for donors of allogeneic blood donations. Official Journal of the European Union. Luxembourg: Publications Office of the European Union. 6.7.2018: L 170/50. Available from: https://eur-lex.europa.eu/ legal-content/EN/TXT/PDF/?uri=CELEX:32018D0945\&from=EN \#page $=50$

16. National Institute for Public Health and the Environment (RIVM). Patient infected with West Nile virus in the Arnhem region. Bilthoven: RIVM; 2020. Available from: https://www.rivm.nl/en/news/ patient-infected-with-west-nile-virus-in-arnhem-region

17. Esser $H J$, Liefting $Y$, Ibáñez-Justicia A, van der Jeugd $H$, van Turnhout CAM, Stroo A, et al. Spatial risk analysis for the introduction and circulation of six arboviruses in the Netherlands. Parasit Vectors. 2020;13(1):464. https://doi. org/10.1186/s13071-020-04339-0 PMID: 32912330

\section{License, supplementary material and copyright}

This is an open-access article distributed under the terms of the Creative Commons Attribution (CC BY 4.0) Licence. You may share and adapt the material, but must give appropriate credit to the source, provide a link to the licence and indicate if changes were made.

Any supplementary material referenced in the article can be found in the online version.

This article is copyright of the authors or their affiliated institutions, 2020. 